\title{
Characterization of vector communities and biting behavior in South Sulawesi with host decoy traps and human landing catches
}

Jenna R. Davidson ${ }^{1 *}$, Robert N. Baskin ${ }^{1}$, Hajar Hasan², Timothy A. Burton ${ }^{1}$, Muhammad Wardiman², Nur Rahma², Fadly R. Saputra², Muhammad Sultanul Aulya², Isra Wahid², Din Syafruddin²,3, Frances M. Hawkes ${ }^{4}$ and Neil F. Lobo'

\begin{abstract}
Background: Indonesia has high mosquito diversity, with circulating malaria and arboviruses. Human landing catches (HLC) are ethically questionable where arboviral transmission occurs. The host decoy trap (HDT) is an exposure-free alternative outdoor sampling device. To determine HDT efficacy for local culicids, and to characterize local mosquito fauna, the trapping efficacy of the HDT was compared to that of HLCs in one peri-urban (Lakkang) and one rural (Pucak) village in Sulawesi, Indonesia.

Results: In Lakkang the outdoor HLCs collected significantly more Anopheles per night $(n=22 \pm 9)$ than the HDT $(n=3 \pm 1)$, while the HDT collected a significantly greater nightly average of Culex mosquitoes $(n=110 \pm 42)$, than the outdoor HLC ( $n=15.1 \pm 6.0)$. In Pucak, there was no significant difference in Anopheles collected between trap types; however, the HDT collected significantly more Culex mosquitoes than the outdoor HLC nightly average $(n=53 \pm 11$ vs $14 \pm 3)$. Significantly higher proportions of blood-fed mosquitoes were found in outdoor HLC ( $n=15 \pm 2 \%)$ compared to HDT $(n=2 \pm 0 \%)$. More blood-fed culicines were collected with outdoor HLC compared to the HDT, while Anopheles blood-fed proportions did not differ. For the HDT, 52.6\%, 36.8\% and 10.5\% of identified blood meals were on cow, human, and dog, respectively. Identified blood meals for outdoor HLCs were $91.9 \%$ human, $6.3 \%$ cow, and 0.9\% each dog and cat. Mosquitoes from Pucak were tested for arboviruses, with one Culex pool and one Armigeres pool positive for flavivirus, and one Anopheles pool positive for alphavirus.

Conclusions: The HDT collected the highest abundance of culicine specimens. Outdoor HLCs collected the highest abundance of Anopheles specimens. Although the HDT can attract a range of different Asian mosquito genera and species, it remains to be optimized for Anopheles in Asia. The high proportion of human blood meals in mosquitoes collected by outdoor HLCs raises concerns on the potential exposure risk to collectors using this methodology and highlights the importance of continuing to optimize a host-mimic trap such as the HDT.
\end{abstract}

Keywords: Culex, Host decoy trap, Surveillance, Sampling device, Behaviour, Indonesia, Arbovirus, Malaria

*Correspondence: jdavids2@nd.edu

${ }^{1}$ Eck Institute for Global Health, University of Notre Dame, Notre Dame, Indiana 46556, USA

Full list of author information is available at the end of the article

(c) The Author(s) 2020. This article is licensed under a Creative Commons Attribution 4.0 International License, which permits use, sharing, adaptation, distribution and reproduction in any medium or format, as long as you give appropriate credit to the original author(s) and the source, provide a link to the Creative Commons licence, and indicate if changes were made. The images or other third party material in this article are included in the article's Creative Commons licence, unless indicated otherwise in a credit line to the material. If material is not included in the article's Creative Commons licence and your intended use is not permitted by statutory regulation or exceeds the permitted use, you will need to obtain permission directly from the copyright holder. To view a copy of this licence, visit http://creativeco mmons.org/licenses/by/4.0/. The Creative Commons Public Domain Dedication waiver (http://creativecommons.org/publicdomain/ zero/1.0/) applies to the data made available in this article, unless otherwise stated in a credit line to the data. 


\section{Background}

The Indonesian archipelago, located along the equator, is made up of over 17,000 islands [1] and is recognized as one of 17 mega-biodiverse countries on the planet [2, 3]. This biodiversity extends to insect vector communities; the archipelago has high Anopheles diversity, with 21 previously confirmed malaria vector species and species complexes [4-8]. Also widespread in Indonesia are Aedes aegypti and Aedes albopictus, the primary vectors of several important arboviruses, including dengue and chikungunya virus [9-12]. Numerous other Aedes species are present in Indonesia and many are capable of transmitting the causative agents of rift valley fever and filariasis [13-20]. Furthermore, species of the genus Culex are ubiquitous throughout much of Indonesia, with many identified as the vectors of filarial parasites, as well as a number of lesser known arboviruses [19, 21-27].

The Republic of Indonesia has the fourth largest population in the world and half of that population live in malaria endemic regions [28, 29]. Disease control relies heavily on vector control measures such as insecticide-treated nets (ITNs) and indoor residual spraying (IRS) [4]. Given the reliance on these vector control measures, the WHO recommends that malaria control programmes also implement entomological monitoring to assess their impact on vector populations, as well as possible changes in intervention efficacy resulting from either changes in mosquito behavior or the emergence of insecticide resistance [30]. The traditional method to monitor vector populations has been the human landing catch (HLC), which involves persons sitting with their lower legs exposed and collecting mosquitoes that come to feed on them during the night [31]. This is the most direct measure of mosquito biting and can be implemented indoors, outdoors, or at any site where transmission may occur, and provides several important entomological endpoints relevant to understanding local epidemiological outcomes. These entomological endpoints are critical data that allow disease control programmes to determine site-specific transmission dynamics and inform the design of evidence-based strategic intervention, as well as identify gaps in protection.

Although HLCs are the sampling method most indicative of vectors biting hosts, they have come under scrutiny due to ethical concerns around exposing collectors to infectious bites [32]. The WHO recommends universal ITN coverage for all persons living in malaria endemic areas [33, 34]; employing persons to stay up all night for the purpose of collecting host-seeking mosquitoes exposes them to malaria and/or other vector-borne diseases that they may have avoided if protected by an ITN. Though ethical concerns about malaria incidence in HLC collectors may be mitigated by two compelling studies that demonstrate no difference in infection rates in the community versus those conducting HLCs, as well as the positive impacts of prophylaxis $[35,36]$, there exists the risk of non-malarial arboviral disease transmission for which there is limited prophylaxis or treatment. Given that Indonesia is a biodiversity hotspot with multitudes of malaria and arboviral vectors, an ethically acceptable sampling method that targets a wide variety of bionomics, is cost effective and easily implemented is imperative to expand disease control and knowledge of vector populations. In the context of Indonesia's high diversity of mosquito species, outdoor sampling is particularly important, as many vectors readily feed outdoors. While alternative indoor sampling methods have been developed for indoor environments, there are limited tools proven to be effective and versatile for attracting and collecting outdoor-biting vectors $[37,38]$.

The host decoy trap (HDT) represents an exposurefree and passive sampling device suitable for outdoor use that attempts to artificially recreate the stimuli that mosquitoes use when host-seeking and feeding [39]. By mimicking visual, olfactory, and thermal stimuli of natural mosquito hosts, an HDT can be used for sampling and killing mosquitoes. Furthermore, these stimuli are all easily manipulated, making the HDT highly versatile for targeting species with known host preferences. When tested outdoors in Burkina Faso, HDTs collected Anopheles coluzzii, a typically indoor-feeding vector, at a ratio of nearly ten to one compared to outdoor human landing catches [39]. It was also found that regardless of season or mosquito genera, HDT catches always outnumbered HLC [39]. More recently, HDTs were evaluated in Kisian and Orego, two villages in western Kenya, to assess its performance in attracting exophagic and zoophagic vectors of malaria using human and cow odors [40]. The study found that a cattle-baited HDT consistently caught more anophelines outdoors than an HLC [40]. However, The Kisian village results contrasted with the original study, as human-baited HDTs caught a lower number of anophelines than HLCs. Local vector populations in western Kenya differ to those in Burkina Faso, and thus the HDT's efficacy may be linked to species-specific differences in vector behaviour and bionomics. Although HDTs have been evaluated using field studies in Africa, focusing on sampling of the Anopheles gambiae (sensu lato) species complex, this tool has not been evaluated as a sampling method in Asia, where it could provide malaria and arboviral endemic regions with a human exposure-free sampling device for entomological investigations $[39,40]$.

To the best of our knowledge, this study is the first evaluation of the human decoy trap outside of Africa, representing the first field test of the behavioural principles employed in the design of the HDT on Asian 
(Indonesian) mosquito fauna. Due to its unique geological history and stable year-round climate, Sulawesi, the largest island of Wallacea, has particularly elevated levels of species richness and endemism [41-43] and was therefore chosen as the location for the study. Furthermore, no studies surveying the local mosquito compositions or bionomics in Sulawesian areas of Lakkang or Pucak villages have been published. Our aims were to (i) evaluate the efficacy of the HDT trap relative to outdoor HLCs with respect to species catch frequency, abdominal status, and blood meal hosts and (ii) establish basic information regarding species composition, host preferences, and flight activity in Lakkang and Pucak villages in Sulawesi, Indonesia.

\section{Methods \\ Study setting Lakkang}

Located in Tallo, Makassar Regency of South Sulawesi, Lakkang Village is $3.9 \mathrm{~km}$ from Makassar city center. However, this peri-urban village is surrounded by rivers, making the isolated location distinct from its large neighboring city (Fig. 1a-c). The village covers approximately $1 \mathrm{~km}^{2}$ and has a population of approximately 1200 inhabitants, primarily engaged in rice farming and fishing. Typical dwellings here are based on an open concept two-story wood and plaster construction with metal roof and open-air access to outdoors much of the day and evening. Lakkang is considered to be malaria receptive. Dengue is diagnosed by platelet count and/or symptoms due to lack of suitable infrastructure (IW, unpublished data).

\section{Pucak}

Pucak Village is situated in Tompu Bulu, Maros Regency, South Sulawesi Province (Fig. 1a, b, d). Approximately $31.9 \mathrm{~km}$ from the center of Makassar city, Pucak represents a rural area adjacent to Balai Taman Nasional Bantimurung Bulusaraung national forest. Pucak is approximately $1 \mathrm{~km}^{2}$ with a population of approximately 500 inhabitants and the main local economic activity is corn and rice farming. Here, the majority of housing consists of a one-room wooden construction on stilts, with permanent openings to the outside (open windows and doors and open-structured floor panels). Human excursions into the surrounding forested area represent points of contact between wildlife and humans. Pucak is considered to be malaria receptive. There are no data for dengue cases in Pucak.

\section{Study design}

In both Lakkang and Pucak, collections were performed between April and May 2017, during the rainy season, for 2 weeks, on 4 consecutive nights each week (Table 1). Previous data collections (IW, unpublished data) in Lakkang and Pucak indicated primary mosquito activity between 18:00-00:00 $\mathrm{h}$; therefore, collections were performed during this time. In Lakkang, there were three collection sites; Site 1 and 2 were outdoors, and Site 3 was indoors (Fig. 1c). Outdoor HLC and HDT trap locations were swapped on consecutive nights between Sites 1 and 2 in a cross-over design to prevent location bias (Table 1). In Pucak there were another three collection sites: Site 4 and Site 5 were outdoors, and Site 6 was indoors (Fig. 1d). Outdoor HLC and HDT trap locations here were switched on consecutive nights between Sites 4 and 5 (Table 1). Indoor HLCs were only performed at Sites 3 and 6 and their locations were not moved. Additionally, outdoor HLC and indoor HLC collectors switched locations every night after $3 \mathrm{~h}$ to remove collector bias. For all 6 collection nights in both villages environmental data, including nightly temperature, relative humidity, heat stress index, dew point, station pressure and density altitude were measured every minute using a Kestrel DROP D2 Wireless Temperature \& Humidity Data Logger (www.kestrelinstruments.com).

\section{Trap description \\ Human landing catches (HLCs)}

HLCs were conducted as described by Gimnig et al. [35]. Collections were performed between 18:00 $\mathrm{h}$ and 00:00 h. There were four HLC collectors each night: two indoor and two outdoors. Collectors swapped positions halfway through the collection shift, at 21:00 h, to control for bias. Mosquitoes were placed in collection cups labelled according to the hour they were collected. Additionally, all collector positions were randomized at the start of each night. Outdoor HLCs were done to enable the comparison of outdoor HLC to the outdoor HDT, while indoor HLC collections enabled the comparison of indoor HLC to outdoor HLC.

\section{Host decoy trap (HDT)}

HDTs were produced by Biogents AG (Regensburg, Germany) based on previously described research [39] and prepared as described in Abong'o et al. [40]. The only deviation from this method was that the PVC pipe used to vent odors from the person in the tent was reduced from $10 \mathrm{~m}$ to $4.5 \mathrm{~m}$ in length. In summary, a collector slept in a one-person tent during the collection period (18:00 $\mathrm{h}$ to $00: 00 \mathrm{~h}$ ) and human odors from the tent were vented, via a pipe and fan, at the base of the HDT (Biogents). The HDT comprised a black cylinder, the surface of which was maintained at a temperature of $30-40{ }^{\circ} \mathrm{C}$ via hot water and wrapped in an adhesive plastic sheet (Barrettine Environmental Health, Bristol, UK). Mosquitoes 


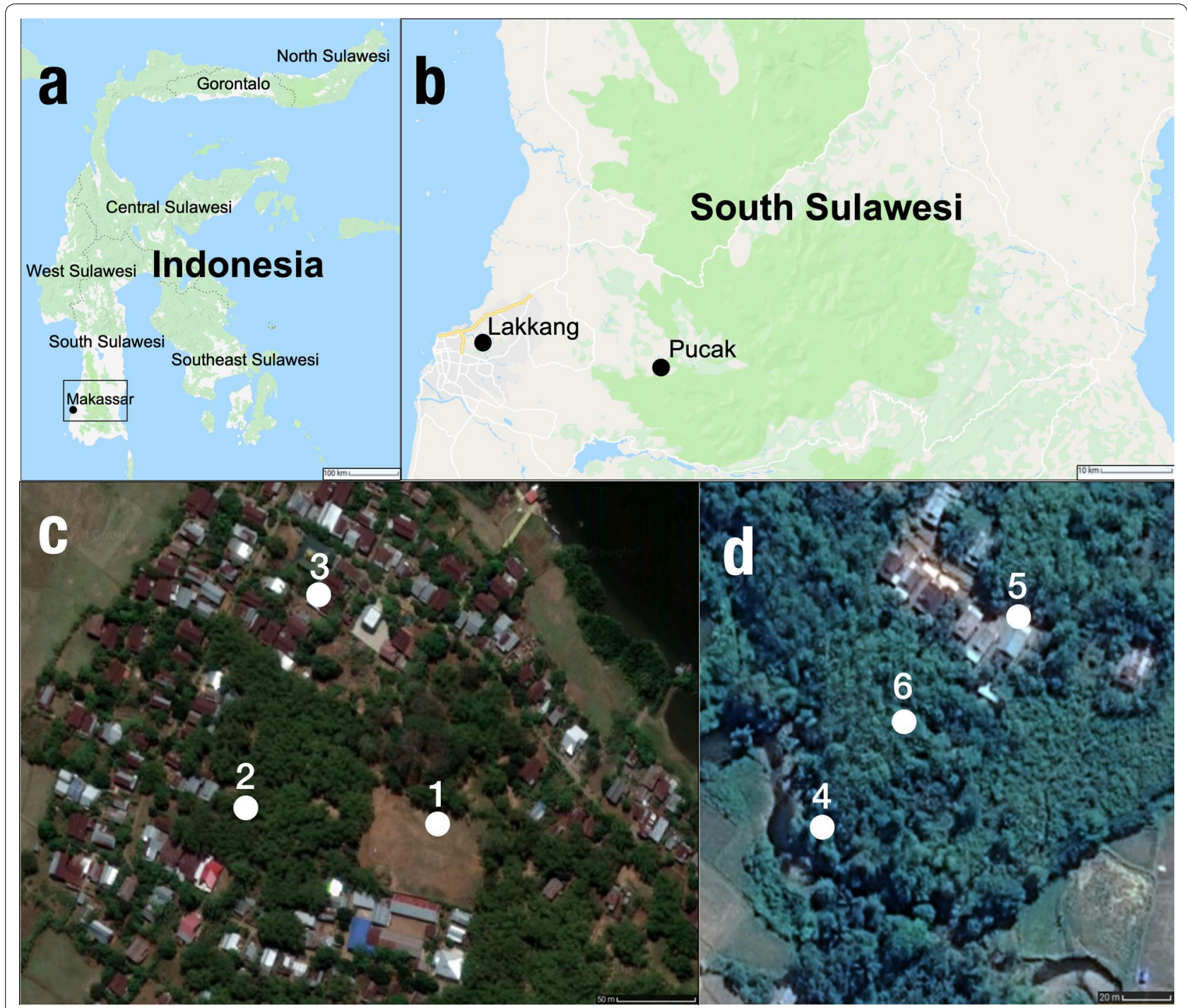

Fig. 1 Study locations and collection sites in South Sulawesi, Indonesia. a Sulawesi, Indonesia. b Lakkang and Pucak village locations in South, Sulawesi, Indonesia. c Collection sites one, two, and three in Lakkang. $\mathbf{d}$ Collection sites four, five, and six in Pucak

are attracted to the host odors from the tent and induced to land by the visual and thermal properties of the HDT; they land and are trapped on the adhesive surface. At the end of every collection period, the adhesive sheet was removed, and trapped mosquitoes were extracted using glue board solvent (MobeMoat Solvent; Barrettine Environmental Health), with only very infrequent loss of body parts. Collections with HDT were performed at the outdoor collection sites only. HDT collections were done in $4 \mathrm{~h}$ shifts (18:00-00:00 h), with one collector inside the HDT tent per night. The single collector inside the HDT tent would rotate randomly on consecutive nights to remove collector bias.

\section{Mosquito collections}

Collection village, site, date, collector identity, hour, genus, sex, and abdominal status were recorded for each mosquito collected by the HLC method. For each mosquito collected using the HDT, all the above data were recorded except for hour of collection. Mosquito morphological identifications were based on multiple taxonomic keys based on genera [44, 45]. For mosquitoes collected in Lakkang, at the end of every collection period, mosquitoes were stored individually in $1.5 \mathrm{ml}$ Eppendorf tubes with silica desiccant for further processing. Mosquitoes collected in Pucak were dissected at the end of each collection period; the heads and thoraxes were stored individually in $1.5 \mathrm{ml}$ Eppendorf tubes with 
Table 1 Collection study cross-over design for Lakkang and Pucak

\begin{tabular}{|c|c|c|c|c|c|}
\hline Week & Site & Day 1 & Day 2 & Day 3 & Day 4 \\
\hline \multicolumn{6}{|c|}{ Lakkang } \\
\hline \multirow[t]{3}{*}{1} & Site 1 & HDT & $\begin{array}{c}\text { Outdoor } \\
\text { HLC }\end{array}$ & HDT & Outdoor HLC \\
\hline & Site 2 & $\begin{array}{c}\text { Outdoor } \\
\text { HLC }\end{array}$ & HDT & $\begin{array}{c}\text { Outdoor } \\
\text { HLC }\end{array}$ & HDT \\
\hline & Site 3 & Indoor HLC & Indoor HLC & Indoor HLC & Indoor HLC \\
\hline \multirow[t]{3}{*}{2} & Site 1 & HDT & $\begin{array}{c}\text { Outdoor } \\
\text { HLC }\end{array}$ & HDT & Outdoor HLC \\
\hline & Site 2 & $\begin{array}{c}\text { Outdoor } \\
\text { HLC }\end{array}$ & HDT & $\begin{array}{c}\text { Outdoor } \\
\text { HLC }\end{array}$ & HDT \\
\hline & Site 3 & Indoor HLC & Indoor HLC & Indoor HLC & Indoor HLC \\
\hline \multicolumn{6}{|l|}{ Pucak } \\
\hline \multirow[t]{3}{*}{3} & Site 4 & HDT & $\begin{array}{c}\text { Outdoor } \\
\text { HLC }\end{array}$ & HDT & Outdoor HLC \\
\hline & Site 5 & $\begin{array}{c}\text { Outdoor } \\
\text { HLC }\end{array}$ & HDT & $\begin{array}{c}\text { Outdoor } \\
\text { HLC }\end{array}$ & HDT \\
\hline & Site 6 & Indoor HLC & Indoor HLC & Indoor HLC & Indoor HLC \\
\hline \multirow[t]{3}{*}{4} & Site 4 & HDT & $\begin{array}{c}\text { Outdoor } \\
\text { HLC }\end{array}$ & HDT & Outdoor HLC \\
\hline & Site 5 & $\begin{array}{c}\text { Outdoor } \\
\text { HLC }\end{array}$ & HDT & $\begin{array}{c}\text { Outdoor } \\
\text { HLC }\end{array}$ & HDT \\
\hline & Site 6 & Indoor HLC & Indoor HLC & Indoor HLC & Indoor HLC \\
\hline
\end{tabular}

Abbreviations: HDT, host decoy trap; $\mathrm{HLC}$, human landing catches

$50 \mu \mathrm{l}$ of RNAlater (Thermo Fisher Scientific, Waltham, USA) (for arbovirus identification) and the abdomens in $1.5 \mathrm{ml}$ Eppendorf tubes with silica desiccant for further processing.

\section{Molecular processing}

All Anopheles mosquitoes $(n=392)$ were sequenced at the mitochondrial DNA cytochrome $c$ oxidase subunit 1 ( $\operatorname{cox} 1$ ) locus for species identification. DNA was extracted from individual specimens using a modified version of the simple alkaline method by Rudbeck \& Dissing [46]. Individual mosquitoes were ground in $1.5 \mathrm{ml}$ tubes with $80 \mu \mathrm{l}$ of $0.2 \mathrm{~N} \mathrm{NaOH}$ and incubated at $75{ }^{\circ} \mathrm{C}$ for $10 \mathrm{~min}$. After incubation, $29 \mu \mathrm{l} 1 \mathrm{M}$ Tris, pH 8.0 and $891 \mu \mathrm{l}$ of $\mathrm{ddH}_{2} \mathrm{O}$ was added and the tubes inverted 10 times. DNA was suspended in a final volume of $1000 \mu$ l containing $0.016 \mathrm{M} \mathrm{NaOH}$ and $0.029 \mathrm{M}$ Tris- $\mathrm{HCl}, \mathrm{pH}$ 8.0. The cox1 gene was amplified using LCO and $\mathrm{HCO}$ primers $[47,48]$. Each reaction contained $1 \times$ Taq buffer $(50 \mathrm{mM} \mathrm{KCl,} 10 \mathrm{mM}$ Tris $\mathrm{pH} 9.0$ and $0.1 \%$ Triton $\mathrm{X}), 1.5 \mathrm{mM} \mathrm{MgCl}_{2}, 200 \mu \mathrm{M}$ dNTPs, 5 pmol of each primer, 1 unit of Taq DNA polymerase, and $1 \mu \mathrm{l}$ of genomic DNA as prepared above. Amplification was performed in $25 \mu \mathrm{l}$ volumes in 96-well PCR plates (Dot Scientific, Burton, USA) in a Mastercycler Nexus thermocycler (Eppendorf, Hamburg, Germany).
Thermocycling conditions for cox 1 were as in Lobo et al. [47]. PCR products were size fractionated by electrophoresis in $2 \%$ agarose gels stained with SYBR ${ }^{\mathrm{TM}}$ Safe (Invitrogen, Carlsbad, CA, USA) and visualized under UV light. DNA cleanup and sequencing were conducted as in Lobo et al. [47] and St. Laurent et al. [48].

\section{Sequence analysis and species identification}

Starting with a minimum match of $95 \%$, the Seqman Pro Assembler (Lasergene v 10.1.1; www.dnastar.com) was used to align cox 1 sequences. Using single nucleotide polymorphisms (SNPs), contigs were divided into subcontigs. Consensus sequences were manually inspected for insertions, deletions, and repeat regions to ensure these sequence differences did not inflate divergence and decrease identity scores. cox 1 sequences were assembled into final species identities using 95\% identity, as mitochondrial lineages are more apt to diverge within a species $[49,50]$. Species were identified by comparing (BLASTn and BOLD) consensus sequences of the cox 1 contigs to the databases [51].

\section{Blood-meal analysis}

Polymerase chain reaction (PCR) amplification of the mitochondrial cytochrome $b$ gene was performed on all 163 blood-fed samples collected during the study. For amplification the following primer sets were utilized: L2513 (5'-GCC TGT TTA CCA AAA ACA TCA C-3') and H2714 (5'-CTC CAT AGG GTC TTC TCG TCT T-3') ( 244 bp; see [52]); as well as L14841 (5'-CCA TCC AAC ATC TCA GCA TGA TGA AA-3') and H15149 (5'CCC TCA GAA TGA TAT TTG TCC TCA- $\left.3^{\prime}\right)(\sim 358$ bp, see [53]). PCR conditions were the same as above. Thermocycling conditions were as follows: $95{ }^{\circ} \mathrm{C}$ for $5 \mathrm{~min}$; 40 cycles of $94{ }^{\circ} \mathrm{C}$ for $30 \mathrm{~s}, 60{ }^{\circ} \mathrm{C}$ for $30 \mathrm{~s}$, and $72{ }^{\circ} \mathrm{C}$ for $30 \mathrm{~s}$; followed by an incubation at $72{ }^{\circ} \mathrm{C}$ for $5 \mathrm{~min}$. PCR products were size fractionated by electrophoresis in $2 \%$ agarose gels stained with $\mathrm{SYBR}^{\mathrm{TM}}$ safe (Invitrogen) and visualized under UV light. DNA cleanup and sequencing were conducted as in Lobo et al. [47] and St Laurent et al. [48].

\section{Arboviruses identification}

Heads and thoraxes of mosquitoes ( $n=665$ out of 672 ) from Pucak were tested for arboviruses. Individual specimens were pooled in groups of up to 30 based on genus to maximize efficiency: Aedes, Anopheles, Armigeres and Culex. A standard TRIzol RNA extraction as described by the manufacturer (Invitrogen) was used to isolate viral RNA. Extracted RNA was stored at $-20^{\circ} \mathrm{C}$ until further testing. After RNA extraction, a reverse-transcriptase 
PCR was performed following the protocol for SuperScript III one-step RT-PCR System with Platinum Taq DNA Polymerase (Invitrogen) for all specimens using previously described primers: Flavivirus $F\left(5^{\prime}\right.$-TAC AAC ATG ATG GGA AAG AGA GAG AA-3') and Flavivirus R (5'-GTG TCC CAG CCG GCG GTG TCA TCA GC-3'); Alphavirus F (5'-(CT)AG AGC (AGT)TT TTC GCA (CT)(GC)T (AG)GC (ACT) (AT)-3') and Alphavirus $\mathrm{R}$ ( $5^{\prime}$-ACA $\mathrm{T}(\mathrm{AG}) \mathrm{A}$ AN(GT) GNG TNG T(AG)T C(AG)A ANC C(AGT)A (CT)CC-3'); and Bunyavirus F (5'-CTG CTA ACA CCA GCA GTA CTT TTG AC-3') and Bunyavirus R (5'-TGG AGG GTA AGA CCA TCG TCA GGA ACT G-3') [54-57].

\section{Statistical analysis}

Statistical analyses were completed in $\mathrm{R}$ version 3.5.2 [58]. Catch abundance was analyzed using generalized linear models (GLMs; R package MASS [59]) with negative binomial distributions, which provided better fits to the 0-inflated data than models using Poisson distributions, followed by post-hoc Tukey comparisons between collection methods (R package multcomp [60]). When set as a predictor, collection site did not significantly affect catch $\left(X^{2}=4.4209, P=0.219\right)$ and so was not included as a factor in subsequent GLMs. HLC collectors working in pairs created a larger plume of $\mathrm{CO}_{2}$ and other olfactory cues, likely impacting mosquito numbers considerably [61]. Therefore, to normalize this result relative to the HDT, all nightly HLC collection results were divided by two, as collectors worked in pairs for HLC and singly for HDT. Sample size for indoor HLC Anopheles specimens was too low to examine biting activity in either Lakkang or Pucak individually.

\section{Results}

A total of 2292 mosquitoes were collected in the study. Lakkang collections produced 1620 specimens, and Pucak 672. Across both study sites, the HDT collected 1361 mosquitoes, while the outdoor HLC collected 864 and the indoor HLC collected 67. Overall mean nightly catches were $85.1 \pm 19.68$ for the HDT, $27.3 \pm 6.40$ for the outdoor HLCs and $2.9 \pm 0.88$ for the indoor HLCs.

\section{Molecular species determination}

The cox 1 sequences of 382 Anopheles mosquito specimens were aligned into nine sequence groups with a stringency of greater than $95 \%$ identity within each group (Table 2). Cox 1 database searches enabled identification of the following six sequence groups to species: An. barbirostris; An. epiroticus; An. peditaeniatus; An. vagus; Cx. bitaeniorhynchus; and Ae. vexans (Table 2).
For Anopheles consensus sequence groups two, four, and five, BLASTn and BOLD sequence homology differed, and these groups were tentatively labelled $A n$. epiroticus/An. sundaicus (s.l.), An. nitidus/An. letifer, and An. nigerrimus/An. letifer, respectively (Table 2).

In Lakkang, 7 species of Anopheles mosquitoes $(n=373)$ were collected. Anopheles barbirostris made up the majority of the collection $(83.2 \%$; 311/373), with smaller proportions of An. epiroticus/An. sundaicus (s.l.) $(8.6 \%$; 32/373), An. epiroticus $(3.5 \% ; 13 / 373)$, An. nitidus/An. letifer (1.9\%; 7/373), An. nigerrimus/An. letifer (1.3\%; 5/373), and $<1$ of both An. peditaeniatus $(0.8 \% ; 3 / 373)$ and An. vagus $(0.5 \% ; 2 / 373)$. Three specimens were morphologically misidentified as Anopheles and consequently molecularly verified as $C x$. bitaeniorhynchus and Ae. vexans. Outdoor HLC collected all seven species of Anopheles mosquitoes in Lakkang as well as the single $A e$. vexans specimen. Indoor HLC and HDT collected three of these species of anophelines: An. barbirostris, An. epiroticus/An. sundaicus (s.l.), and An. epiroticus.

In Pucak, two species of Anopheles mosquitoes $(n=6)$ were collected, An. barbirostris $(n=5)$ and $A n$. vagus $(n=1)$. Both of these species were collected using outdoor HLC. Two morphologically identified Anopheles specimens were molecularly identified as Cx. bitaeniorhynchus. These Culex specimens were collected with HDT and indoor HLC.

\section{Nightly catch comparison by collection method Lakkang}

Mosquito abundance in Lakkang differed by trap type; more Anopheles were collected by the outdoor HLC, while the HDT collected a greater abundance of Culex mosquitoes. For Anopheles, the outdoor HLCs collected significantly more mosquitoes per night $\left(22.0 \pm 8.6 ; F_{(1}\right.$, $\left.{ }_{14)}=23.275, P<0.0001\right)$ than the HDT $(3.0 \pm 1.3)$, representing a seven-fold difference (Fig. 2a). Meanwhile, the HDT collected a significantly greater nightly average of $110.1 \pm 42.4$ Culex mosquitoes, over seven times more compared to the outdoor HLC nightly average of $15.1 \pm 6.0 \quad\left(F_{(1,14)}=8.1756, P=0.004\right) \quad$ (Fig. 2a). Indoor HLCs were not statistically compared to other trapping methods due to low sample size of total indoor catches in Lakkang $(n=43)$.

\section{Pucak}

Mosquito abundance in Pucak also differed by trap type; the HDT again collected a greater abundance of Culex collections compared to the HLC. For Anopheles, the HDT collected a nightly mean of $0.1 \pm 0.1$ mosquitoes and there was no significant difference in this compared to outdoor HLC, which caught a mean of $0.6 \pm 0.3$ per 
night $\left(F_{(1,14)}=2.9109, P=0.088\right)$ (Fig. $\left.2 b\right)$.The HDT collected a nightly average of $52.9 \pm 11.2$, significantly more Culex mosquitoes compared to the outdoor HLC nightly average of $13.6 \pm 3.1\left(F_{(1,14)}=17.137, P<0.0001\right)$ (Fig. 2b). Indoor HLCs were not statistically compared to other trapping methods due to low sample size of total indoor catches in Pucak $(n=24)$.

\section{Genera composition by collection method}

First, trap collections were compared by the proportion of a given genus out of total collections of that genus at each site. In Lakkang, the majority of Anopheles specimens were collected with outdoor HLCs, $85.7 \%$ (Fig. 3a). The HDT and indoor HLCs collected $11.8 \%$ and $2.5 \%$ of Anopheles, respectively (Fig. 3a). The majority of Culex specimens were collected with the HDT, $86.7 \%$. Outdoor HLCs and indoor HLCs collected $11.7 \%$ and $1.6 \%$ of Culex mosquitoes, respectively (Fig. 3a). Aedes species collected with the HDT, outdoor HLC and indoor HLC consisted of $53.2 \%, 42.6 \%$ and $4.3 \%$, respectively (Fig. 4a). Outdoor HLCs collected over half of Mansonia mosquitoes $57.1 \%$ with HDTs collecting the remaining $42.9 \%$ of Mansonia specimens (Fig. 3a). There were no Armigeres mosquitoes collected in Lakkang (Fig. 3a).

In Pucak, outdoor HLCs collected of half of Anopheles species in Pucak, 57.1\%, followed by indoor HLC, $28.6 \%$, then the HDT $14.3 \%$ (Fig. 3b). The HDT again collected the majority of the total Culex mosquito collection (78.3\%), while outdoor HLCs and indoor HLCs collected $19.8 \%$ and $1.9 \%$, respectively (Fig. 3b). Outdoor and indoor HLCs each collected $50 \%$ of Aedes species in Pucak while the HDT and outdoor HLC each collected 50\% of Armigeres mosquitoes (Fig. 3b). There were no Mansonia mosquitoes collected in Pucak (Fig. 3b).
Secondly, traps were evaluated by looking at a single trapping method's rate of collection of a genus compared to other genera. For instance, the overwhelming majority of mosquitoes collected by the HDT were Culex in both Lakkang (94.1\%) and Pucak (99.5\%), with 2.6\% Anopheles, 2.7\% Aedes, and 0.6\% Mansonia in Lakkang and 0.2\% Anopheles and 0.2\% Armigeris in Pucak (Fig. 4a). This differed markedly to the genera composition from outdoor HLC, for which Anopheles dominated in Lakkang (54\% of the catch) but accounted for only $3.1 \%$ of the catch in Pucak (Fig. 4b). There was, however, a similar proportion of Culex collected by the outdoor HLC in Pucak (95.5\%) compared to Pucak HDT (99.5\%). Indoor HLCs did not collect any Armigeris or Mansonia mosquitoes. There were similar proportions of Anopheles (20.9\%) and Culex (72.1\%) in Lakkang, but indoor HLC had a higher proportion of Culex (83.3\%) compared to Anopheles and Aedes in Pucak (Fig. 4c).

\section{Blood-meal identification and abdominal status}

Outdoor HLCs collected a significantly higher proportion of blood-fed mosquitoes (66/433) compared to the HDT (23/1360), $0.15 \pm 0.02$ and $0.02 \pm 0.0 \quad(z=9.329$, $P<0.0001$ ) (Fig. 5). Blood-fed culicines collected with the HDT (20/1304) and outdoor HLC (36/226) differed significantly $(z=8.63, P<0.001)$. Whereas, Anopheles blood-fed proportions between the HDT $(1 / 25)$ and outdoor HLC (18/178) were not significantly different $(z=0.946, P=0.975)$.

Engorged females $(n=163)$ were tested for blood meal by PCR to identify the host source (Table 3). For the HDT $(n=19), 52.6 \%, 36.8 \%$ and $10.5 \%$ of identified blood meals were on cows, humans and dogs respectively. For mosquitoes collected with the HDT,

Table 2 Overview of molecular identifications. Table represents the 382 morphologically identified Anopheles specimens that were sequenced using the cox 1 locus. Final species identifications are based on both cox1 BLASTn and BOLD database comparisons

\begin{tabular}{|c|c|c|c|c|c|c|}
\hline $\begin{array}{l}\text { Consensus } \\
\text { sequence } \\
\text { groups }\end{array}$ & $n$ & $\begin{array}{l}\text { Collection } \\
\text { method HDT/ } \\
\text { HLC }\end{array}$ & $\begin{array}{l}\text { BLASTn sequence homology } \\
(\% \mathrm{ID})\end{array}$ & $\begin{array}{l}\text { BOLD sequence homology } \\
(\% \mathrm{ID})\end{array}$ & Tentative species ID & Final species ID \\
\hline Group 1 & 316 & $18 / 298$ & An. barbirostris (99) & An. barbirostris (98-96) & An. barbirostris & An. barbirostris \\
\hline Group 2 & 32 & $4 / 28$ & An. epiroticus (97) & An. sundaicus (s.l.) (98-96) & $\begin{array}{l}\text { An. epiroticus/An. sundaicus } \\
\text { (s.l.) }\end{array}$ & Sundaicus Complex \\
\hline Group 3 & 13 & $2 / 11$ & An. epiroticus (97) & An. epiroticus (97-96) & An. epiroticus & An. epiroticus \\
\hline Group 4 & 7 & $0 / 7$ & An. nitidus (96) & An. letifer (98-95) & An. nitidus/An. letifer & Unknown \\
\hline Group 5 & 5 & $0 / 5$ & An. nigerrimus (96) & An. letifer (98-95) & An. nigerrimus/An. letifer & Unknown \\
\hline Group 6 & 3 & $0 / 3$ & An. peditaeniatus (99) & An. peditaeniatus (100-99) & An. peditaeniatus & An. peditaeniatus \\
\hline Group 7 & 3 & $0 / 3$ & An. vagus (95) & An. vagus $(99-90)$ & An. vagus & An. vagus \\
\hline Group 8 & 2 & $1 / 1$ & Cx. bitaeniorhynchus (100) & $\begin{array}{l}\text { Cx. bitaeniorhynchus } \\
(100-94)\end{array}$ & Cx. bitaeniorhynchus & Cx. bitaeniorhynchus \\
\hline Group 9 & 1 & $0 / 1$ & Ae. vexans (99) & Aedimorphus vexans (99-97) & Ae. vexans & Ae. vexans \\
\hline
\end{tabular}



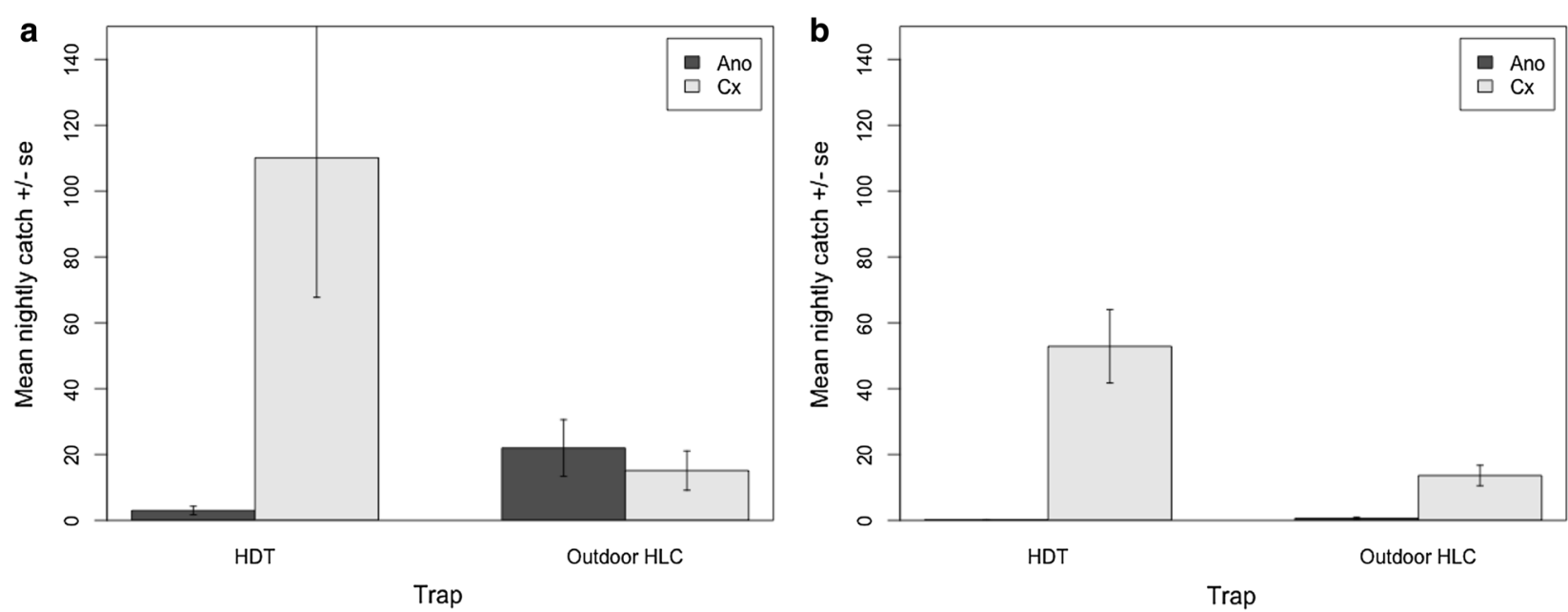

Fig. 2 Nightly catch (mean \pm standard error) of anopheline (Ano) and culicine (Cx) mosquitoes from human decoy trap (HDT) and outdoor human landing catch (HLC) traps in Lakkang (a) and Pucak (b), Sulawesi, Indonesia

a single Aedes and a single Anopheles specimen fed on cows, while the only blood-fed Mansonia mosquito fed on humans (Table 3). The remaining blood-fed Culex mosquitoes collected with the HDT fed on cows, humans and dogs $(n=8,6$ and 2 , respectively). Identified blood meals for outdoor HLCs $(n=111)$ were 91.9\% human, 6.3\% cow, and $0.9 \%$ each dog and cat. Aedes mosquitoes collected with outdoor HLC had fed on humans and cows ( $n=7$ and $n=1$, respectively), as had Anopheles mosquitoes $(n=32$ and $n=2$, respectively). Culex mosquitoes collected with outdoor HLC fed on humans, cows, dogs, and cats $(n=58,41$ and 1$)$ respectively (Table 3 ). The Mansonia mosquitoes collected with outdoor HLC only fed on humans $(n=5)$. Of the Anopheles species that were molecularly identified, 39 had identified blood meals. Anopheles barbirostris (29/39) blood-fed on humans and cows $(n=26$ and $n=3)$, respectively. Anopheles epiroticus/An. sundaicus (s.l.) (5/39), An. epiroticus (3/39), An. nitidus/An. letifer (1/39) and An. peditaeniatus (1/39) all blood-fed on humans.

\section{Arbovirus identification}

Mosquitoes from Pucak tested for arboviruses indicated one Culex pool positive for flavivirus, one Anopheles pool positive for alphavirus, and one Armigeres pool positive for flavivirus.

\section{Biting activity}

Overall biting activity of Anopheles peaked between 18:00-19:00 $\mathrm{h}$ with smaller subsequent peaks between 20:00-21:00 $\mathrm{h}$ and 22:00-23:00 h (Fig. 6a). Overall biting activity of Culex mosquitoes peaked from 22:00-23:00 h
(Fig. 6a). Culex mosquito biting activity in Lakkang experienced a small peak in activity between 19:00-20:00 h followed by a decrease in activity between 20:00-21:00 h (Fig. 6b). Biting activity of Culex mosquitoes rose between 21:00-23:00 $\mathrm{h}$ before decreasing (Fig. 6b). In Pucak biting activity of Culex mosquitoes experienced a small peak between 20:00-21:00 $\mathrm{h}$ followed by a decrease in activity between 21:00-22:00 h (Fig. 6b). Biting activity of Culex mosquitoes increased from 22:00-00:00 h, during the second half of the night (Fig. 6b).

\section{Environmental data}

Average nightly temperature and relative humidity (RH) in Lakkang were $27.5{ }^{\circ} \mathrm{C}$ and $80.8 \% \mathrm{RH}$, and in Pucak were $26.4{ }^{\circ} \mathrm{C}$ and $85.6 \% \mathrm{RH}$ (Table 4 ).

\section{Discussion}

This study found that the HLC caught significantly more Anopheles mosquitoes than HDT, in contrast to results from the HDT pilot study [39]. Conducted in Burkina Faso, Africa, the pilot study consisted of catches from predominantly one anopheline species, An. coluzzii, and found that HDT collections surpassed HLC for all mosquito genera [39]. In this study, outdoor HLCs surpassed HDTs for Anopheles in Lakkang, suggesting that behaviors displayed by African Anopheles vectors may be drastically different than those shown by Indonesian Anopheles vectors. This stresses the need for continued laboratory and field studies to test the responses of different anophelines to specific cues. Only by doing so can the nuances of behaviors be understood and targeted in a 

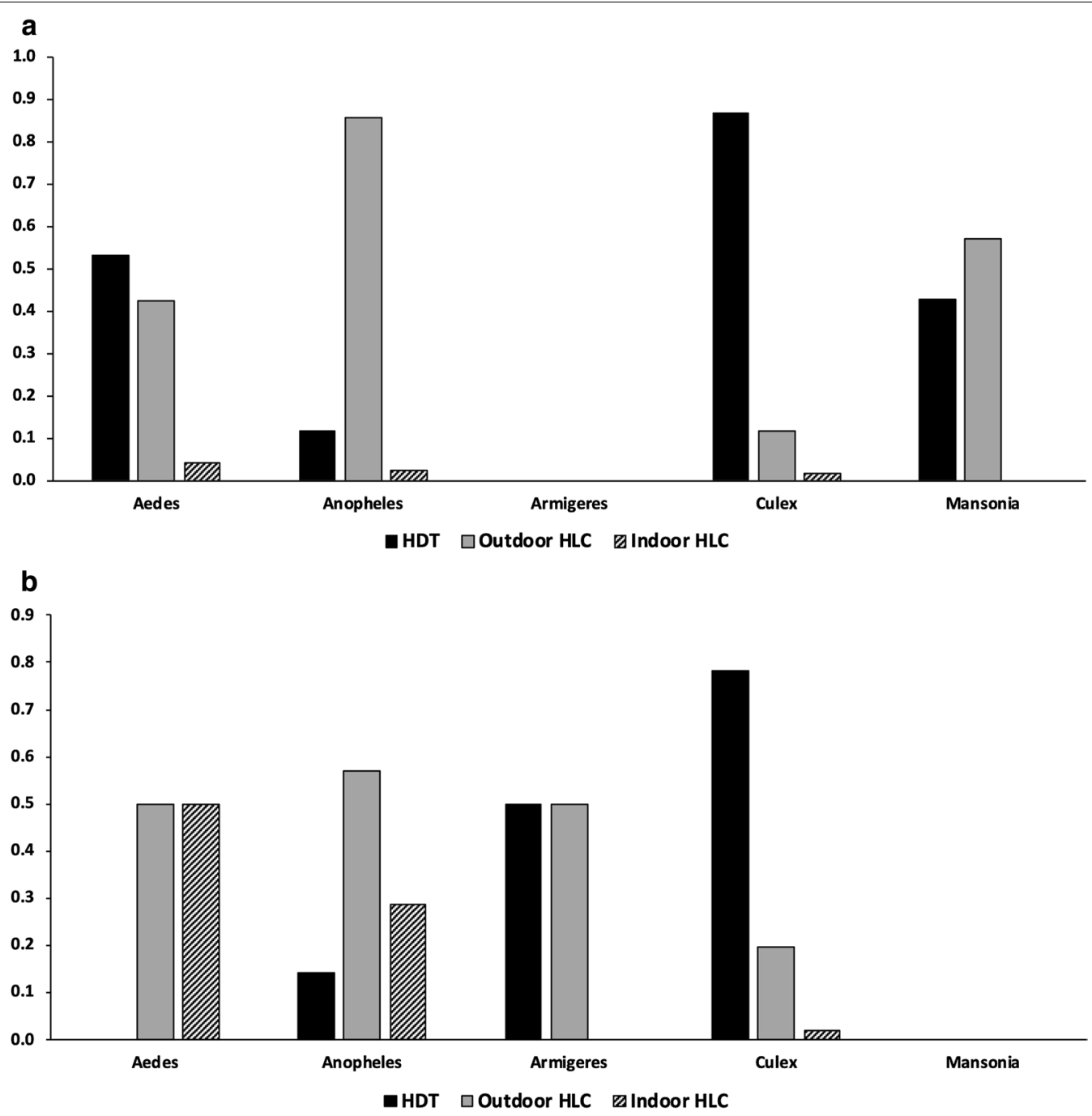

Fig. 3 Comparison of three trapping methods, human decoy trap, outdoor HLC, and indoor HLC by proportion of total mosquitoes collected within a given genus in Lakkang (a) and Pucak (b) Sulawesi, Indonesia

trap like the HDT, providing the evidence-base for locally appropriate innovations in surveillance and control.

The difference in collection performance may be due to the specific behavioral traits of local anopheline species. Based on our results, host-seeking behaviors in Indonesian anophelines are presumably sufficiently different to those of the Gambiae Complex species to lead to differential responses to the host-associated cues used in the HDT. Inclusion and configuration of these cues in trap design has been based on both laboratory behavioral assays and subsequent field-based proof of concept studies [39] that have concentrated on An. gambiae (s.l.). As the HDT was effective at sampling culicines (both in comparison to HLC within this study and relative to previous results), it therefore seems likely that the difference in catch stems from fundamental differences between Indonesian and African anopheline behavior. This challenges the notion that 'universal' tools for sampling or controlling diverse secondary malaria vectors will be effective, implying instead that tailored solutions, adapted to the specific behavior and ecology of local vectors, will be needed. Such tools will require empirical study of these traits in less well understood vector species to provide the basis for locally effective innovations.

St. Laurent et al. [62] identified similar anopheline communities in Cambodia to those found in the present study in Sulawesi, including An. vagus, An. nitidus, An. peditaeniatus and the Barbirostris group. In Thailand, An. epiroticus displayed exophagic and zoophilic preferences and the majority of these species were collected in 

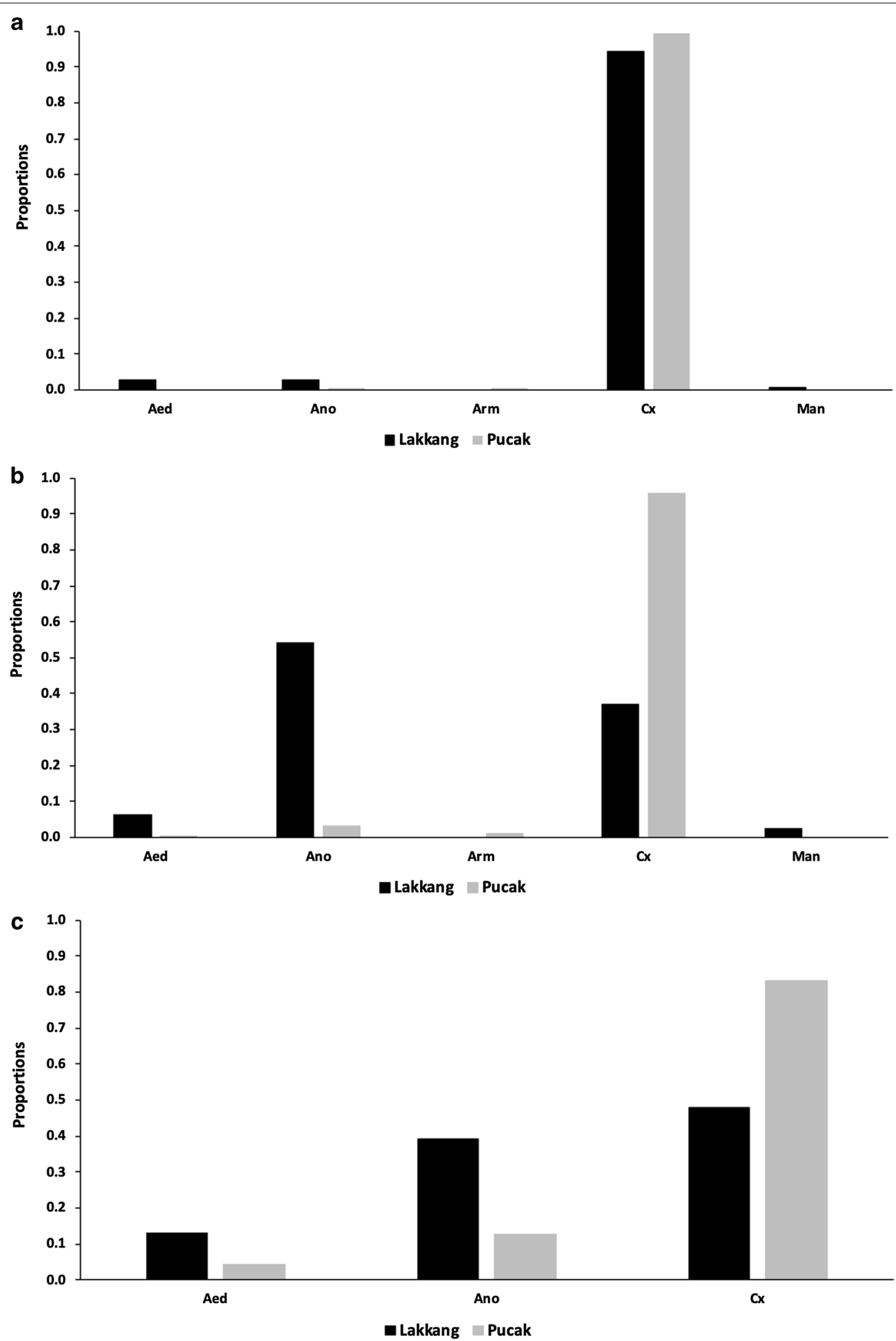

Fig. 4 Relative genera compositions (proportions) of Aedes (Aed), Anopheles (Ano), Armigeris (Arm), Culex (Cx), and Mansonia (Man), from three trapping methods, (a) human decoy trap $(n=1361)$, (b) outdoor human landing catch $(n=864)$ and $(\mathbf{c})$ indoor human landing catch $(n=67)$ in Lakkang and Pucak, Sulawesi, Indonesia 


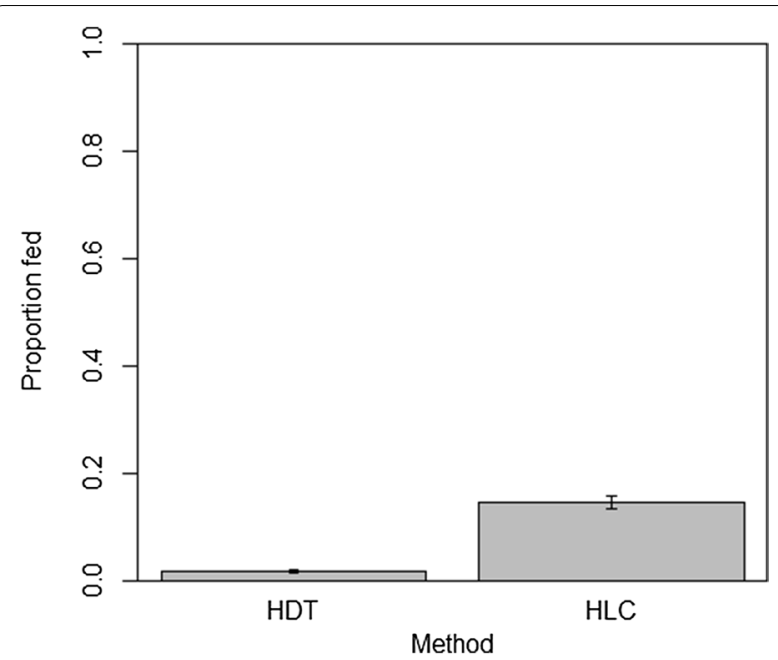

Fig. 5 Proportion of blood-fed mosquitoes collected with the host decoy trap (HDT) compared to outdoor human landing catch (HLC) for the duration of the study

buffalo traps compared to HLC [63]. A study examining host preferences of anophelines in Sri Lanka [64] did not detect any human blood in two species identified in the present study, i.e. An. nigerrimus and An. vagus. Additionally, the human blood index calculated for An. barbirostris was 0.27 , indicating lower human blood meal preference compared to other vectors in the region [64]. Further research will be needed to investigate the strength of this relationship.

The HDT, as configured in this study, appears to be effective for collecting all other mosquito genera, Culex, Mansonia and Armigeres, collecting significantly more
Culex mosquitoes and similar amounts of other genera. Existing sampling methods for these groups have been tested and found to be effective in the Southeast Asian region, including $\mathrm{CDC}$ light traps [65] and tent traps baited with various animal baits [66]. These tend to require less equipment than the current HDT prototype and this would require further product development to improve the practicality of the tool before being considered a viable field method.

Despite their importance in transmitting filariasis $[67,68]$, Japanese encephalitis [69-71], and other lesser known arboviruses [26, 69, 72, 73], little is known about the distribution and bionomics of culicine vectors in Sulawesi, Indonesia. Furthermore, there have been several arboviruses outbreaks in recent Indonesian history including chikungunya virus [12,74], and the isolation of Zika virus from Jakarta and Bali $[66,75]$. Future studies could utilize the HDT for identifying potential vectorborne pathogen exposure risks. This study serves as proof of principle for utilizing the HDT for culicine sampling and surveillance in this region.

Inarguably, outdoor HLCs are optimized for human host-seeking anophelines, as supported by the results of this study and previous literature [76]. Although the previously mentioned HDT studies had success using other configurations, namely cow-baited decoy traps, at collecting Anopheles vectors that feed on humans, the method is still limited in how closely it can mirror outdoor HLCs. Although the risks of utilizing willing, trained volunteers providing informed consent to perform HLCs are widely accepted due to the otherwise impossible to approximate epidemiological risk factors, research demonstrating configurations of the HDT that

Table 3 Number of blood-fed specimens collected and successful host DNA identification groups based on cytochrome $b$ gene analysis

\begin{tabular}{|c|c|c|c|c|c|c|}
\hline $\begin{array}{l}\text { Morphological genera/collection } \\
\text { method }\end{array}$ & $\begin{array}{l}\text { No. of specimens } \\
\text { collected }\end{array}$ & $\begin{array}{l}\text { No. of blood meals } \\
\text { identified }\end{array}$ & Human & Cow & Dog & Cat \\
\hline \multicolumn{7}{|l|}{ HDT } \\
\hline Aedes & 1 & 1 & 0 & 1 & 0 & 0 \\
\hline Anopheles & 1 & 1 & 0 & 1 & 0 & 0 \\
\hline Culex & 20 & 16 & 6 & 8 & 2 & 0 \\
\hline Mansonia & 1 & 1 & 1 & 0 & 0 & 0 \\
\hline Total & 23 & 19 & 7 & 10 & 2 & 0 \\
\hline \multicolumn{7}{|l|}{ Outdoor HLC } \\
\hline Aedes & 9 & 8 & 7 & 1 & 0 & 0 \\
\hline Anopheles & 35 & 34 & 32 & 2 & 0 & 0 \\
\hline Culex & 71 & 64 & 58 & 4 & 1 & 1 \\
\hline Mansonia & 11 & 5 & 5 & 0 & 0 & 0 \\
\hline Total & 126 & 111 & 102 & 7 & 1 & 1 \\
\hline
\end{tabular}



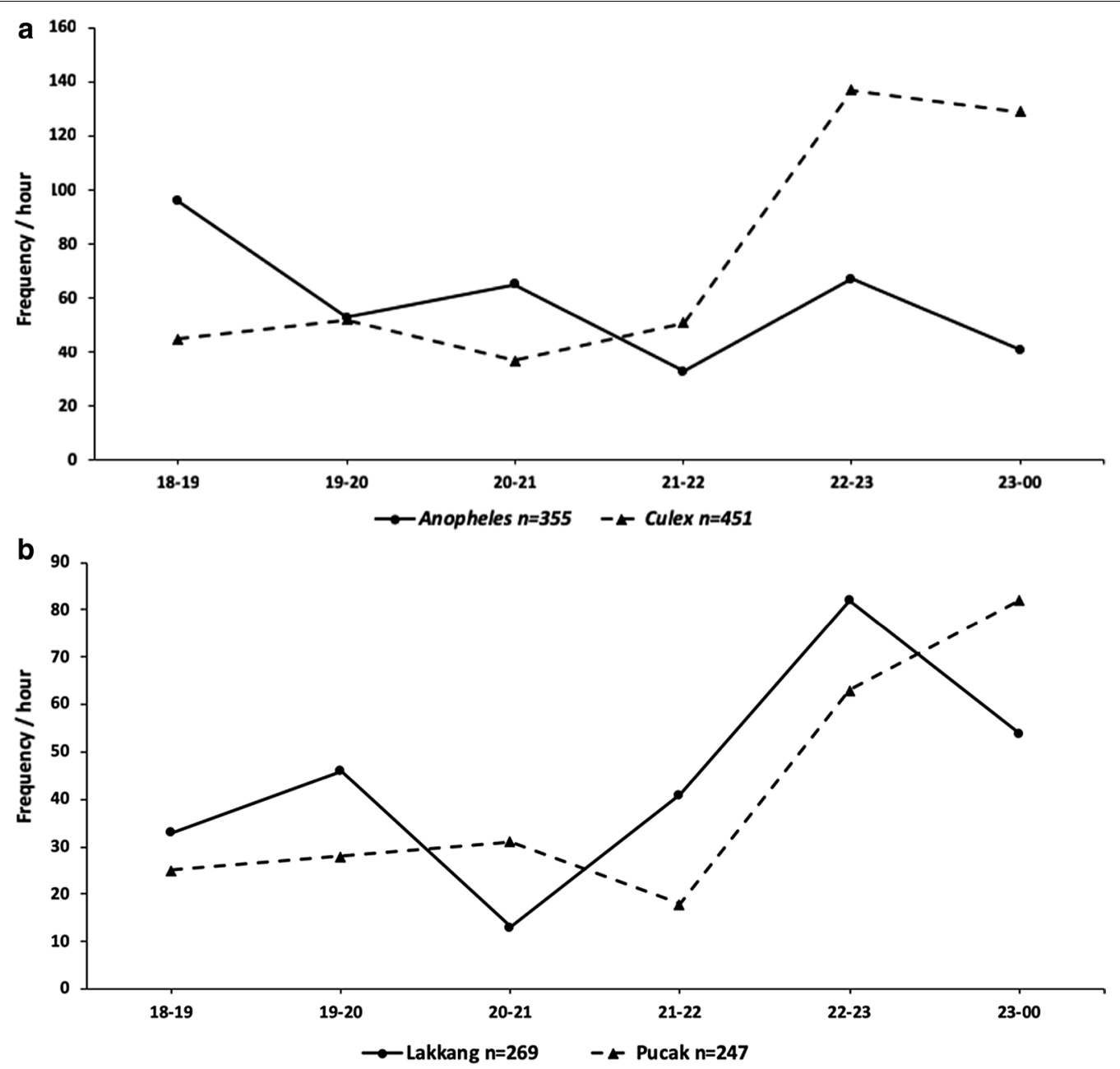

Fig. 6 Biting activity by hour for outdoor HLC for Culex and Anopheles specimens (a) and Culex specimens in Lakkang and Pucak (b). Frequency was calculated as the number of mosquitoes collected utilizing outdoor HLC for each time point throughout the first half of the night

Table 4 Kestrel DROP D2 Wireless temperature and humidity data

\begin{tabular}{lllllcc}
\hline Village & Temperature $\left({ }^{\circ} \mathrm{C}\right)$ & $\begin{array}{l}\text { Relative humidity } \\
(\%)\end{array}$ & $\begin{array}{l}\text { Heat stress index } \\
\left({ }^{\circ} \mathrm{C}\right)\end{array}$ & Dew point $\left({ }^{\circ} \mathrm{C}\right)$ & $\begin{array}{l}\text { Station pressure } \\
(\mathrm{mb})\end{array}$ & $\begin{array}{l}\text { Density } \\
\text { altitude } \\
(\mathrm{m})\end{array}$ \\
\hline Lakkang & 27.5 & 80.8 & 31.5 & 23.8 & 1010.2 & 584.7 \\
Pucak & 26.4 & 85.6 & 30.2 & 23.8 & 998.6 & 669.9 \\
\hline
\end{tabular}

Abbreviations: mb, millibars

more closely mirror HLC collections could potentially eliminate this risk. Although this study failed to demonstrate the ability for the HDT to mimic HLCs, it does demonstrate some of the risk involved; outdoor HLCs collected more blood-fed mosquitoes than HDTs in both Lakkang and Pucak, the majority of this difference is based almost entirely on human blood-fed mosquitoes, which comprised $91.9 \%$ of outdoor HLC blood-fed mosquitoes. Since the HDT protects collectors from mosquito bites and only uses their odors to attract mosquitoes, a possible reason for the majority of human blood meals (and therefore total blood meals) were mosquitoes that fed on HLC collectors. This discrepancy could also be due to the different mosquito compositions collected. Further studies, involving matching DNA from blood-fed mosquitoes to collectors could 
establish the strength of the relationship between HLCs and collector exposure through comparison with HDT blood-fed rates. Given HLCs accounted for a disproportionately high number of blood-fed mosquitoes, their use in entomological studies when risk of arboviral transmission is present should be avoided where possible.

In this study, two pools of mosquitoes tested positive for flavivirus, one Culex and one Armigeres while one Anopheles pool tested positive for alphavirus, highlighting the potential risk to collectors. While there are no reports of any arboviruses in circulation in human populations in Pucak, local diagnostic capacity may limit accurate detection and reporting of these. Viral transmission may be occurring since viruses are present in the mosquito vectors.

Based on the HLC results, this study was able to characterize Anopheles species in a region without previous collection. Of the nine molecularly identified consensus sequences, six could be identified to species: $A n$. barbirostris; An. epiroticus; An. peditaeniatus; An. vagus; $C x$. bitaeniorhynchus; and Ae. vexans. Of the four molecularly identified Anopheles, three are confirmed malaria vectors in Indonesia: An. barbirostris; An. epiroticus; and An. vagus [7, 77-80]. Anopheles peditaeniatus has not been confirmed as a malaria vector in Indonesia; however, it has been shown positive for Plasmodium falciparum by ELISA in Sri Lanka [81] and Thailand [82]. The presence of these species in human-baited traps supports the description of both Makassar and Maros Regencies as malaria receptive areas by regional public health teams (IW, unpublished data). Three specimens were morphologically identified as Anopheles but molecularly confirmed to be $C x$. bitaeniorhynchus and Ae. vexans. Culex bitaeniorhynchus is a vector of Wuchereria bancrofti, Murray Valley encephalitis virus, Japanese encephalitis virus, and Batai virus [83-86], while Ae. vexans is capable of transmitting Eastern equine encephalitis virus, Western equine encephalitis virus, St. Louis encephalitis virus, West Nile virus, and Japanese encephalitis [87-89]. This finding highlights the importance of cross-referencing morphological identifications with molecular identifications, especially in areas of high vector diversity, like Indonesia. Misidentifications resulting from overreliance on a single identification method can have negative downstream effects when determining species' bionomic traits, associations of vector status, entomological inoculation rates, and impacts of control. Inaccurate morphological identification at the genus level stresses the need for employing molecular identification in otherwise morphology-based studies when determining disease vectors and their respective bionomics.
While molecular tools can disambiguate vector identities, they must be based on comprehensive libraries of reference genetic material. In our study, three consensus sequences had conflicting BLASTn and BOLD database results: group 2, 4, and 5. Group 2 belongs to the Sundaicus Complex, a main malaria vector in Indonesia [7]. Group 4 BLASTn database homology identified these specimens as An. nitidus; however, the BOLD database search identified these Anopheles specimens as An. letifer. The discrepancy in the BLASTn and BOLD database sequence results coupled with the presence of cox 1 sequences for An. letifer in BLASTn and An. nitidus in BOLD, and lack of associated sequences in databases could indicate an addition to the Hyrcanus or Umbrosus Group. However, it is far more likely that distributions and phylogenetic relationships between species in these two groups may vary due to the wide geographical distribution of sequences available in databases, complicating interpretation. For example, the An. letifer sequences in GenBank are from Singapore [90], while these An. nitidus sequences in BOLD are from Thailand. Similar results were seen for group 5. Therefore, additional research that implements nuclear and mtDNA sequencing within Indonesia is necessary to accurately identify species that are malaria and arboviral vectors and to create baseline information for nucleotide databases for Sulawesi specifically.

Local Anopheles vector populations were composed of up to seven species, consisting of predominantly $A n$. barbirostris. Seven different Anopheles species were identified in Lakkang, whereas only two Anopheles species were found in Pucak. The diversity in mosquito vectors in two $1 \mathrm{~km}^{2}$ villages further illustrates the biodiversity of the Indonesian archipelago and its ability to host a variety of vectors. Appropriate innovations in surveillance and control, especially in regions of high biodiversity with heterogenous vector ecology and behavior, are undoubtedly a challenge $[4,91]$.

Genera composition varied between Lakkang and Pucak. Aedes, Anopheles and Mansonia were found in higher proportions in Lakkang, while Culex and Armigeres were found in higher proportions in Pucak. These differences are attributed to the presence of available habitats preferred by species of these genera. Lakkang is surrounded on all sides by the Tallo River and the main economic activity is rice farming. Due to its riverine location and predominance of rice paddy land cover, sunlit water bodies are readily available, making the surrounding area an excellent habitat for many Anopheles species, including the three main species found in this study, namely An. barbirostris, An. epiroticus and An. sundaicus (s.l.) [92-94]. Whereas, south of the collection sites in Pucak, there is water run-off from the neighboring river. 
The resulting pools of often stagnant and turbid water are an ideal habitat for Culex larvae [95]. More generally, in North Sulawesi, studies have reported a Culex preference for rain-fed rice fields [96]. The rice fields in both Lakkang and Pucak are rain-fed and this could explain the high proportions of Culex specimens relative to Anopheles specimens at these study sites. However, this could also be a result of zoophilic Anopheles being present at the sites that were not targeted by the trapping regimen in this study. Lastly, previous studies have shown an increase in the host-seeking behaviors of An. gambiae (s.s.) and an increase in Mansonia mosquito populations during periods of rising relative humidity $[97,98]$. The higher relative humidity in Pucak with the available bodies of water for Culex larvae could explain the elevated numbers of Culex mosquitoes collected in Pucak, however future studies would need to further investigate this relationship.

Indoor and outdoor mosquito biting profiles were compared with HLC. Indoor HLCs collected low proportions of all mosquito genera in both villages compared to outdoor HLCs, despite the predominantly open housing structures found in both study villages. Given there are limited physical barriers to impede mosquito ingress into dwellings, these low numbers indicate mosquito biting is preferentially occurring outdoors, suggesting implementation of outdoor interventions may be most effective in both Lakkang and Pucak, Indonesia, if disease transmission is confirmed in this susceptible region.

Biting activity is an important factor for determining the behaviors and possible transmission times for vectorborne diseases. Anopheles mosquitoes peaked in activity between 18:00-19:00 $\mathrm{h}$. This corroborates previous reports of An. barbirostris, the predominate molecularly identified vector in this study, that indicate An. barbirostris feeds outdoors in the early evening [99]. However, the biting activity for An. barbirostris are dependent on geographical location in Indonesia [7]. There have been no attempts to evaluate the biting activity of Culex mosquitoes in Lakkang or Pucak. In both villages, Culex activity increased during the second half of the night peaking at 22:00-23:00 $\mathrm{h}$ in Lakkang and continuing to rise up to the end of collections at 00:00 h in Pucak. Although collections in this study represent a fourth of the daily timeline, it aligns with other field studies from India and Thailand that have reported peaks in $C x$. quinquefasciatus flight activity around 22:00 h $[100,101]$. In Japan, the average density of $C x$. pipiens was found to increase until 22:00 h [102]. A limitation of this study was that molecular identification was not performed on culicine mosquitoes. The lack of Culex biting activity documentation in Indonesia stresses the importance of continued recording of mosquito biting times so accurate local transmission risks can be determined.

Identifying and evaluating species compositions and behaviors in Indonesia will require continued interest and investment from researchers. The region's high biodiversity and archipelagic geography make efforts to comprehensively survey the islands either prohibitively expensive or piecemeal and individualized to localities. Furthermore, behavior of local vector fauna differs markedly to the relatively well-studied African vectors. Combining longitudinal data sets for trap types and comparison studies will yield better understanding for ethical trapping and effective intervention practices as the world continues to pursue the elimination of malarial and arboviral transmission.

\section{Conclusions}

Although the HDT collected the highest density of mosquitoes in this study, this was entirely due to culicine specimens, which were not evaluated at the species level. Outdoor HLCs collected the highest abundance of anopheline specimens. Therefore, although the stimuli presented in the HDT can be employed to sample a range of different Asian mosquito genera and species, it remains to be optimized for specific host-seeking behaviors in Asia. The high proportion of human blood meals from mosquitoes collected by outdoor HLCs reinforces what is known about the exposure risk to collectors for the methodology and the importance of continuing to optimize a host-mimic trap such as the HDT. Further study involving matching DNA from blood-fed mosquitoes to collectors could establish the strength of the relationship between HLCs and collector exposure, especially through comparison with mosquito blood-meals of a host-mimic trap, such as an optimized HDT. The HDT could also be evaluated as a potential outdoor intervention strategy if the high capture rates can be demonstrated to impact overall mosquito populations within a locality.

\section{Abbreviations \\ HDT: host decoy trap; HLC: human landing catch; ITN: insecticide-treated net; GLM: generalized linear model; PCR: polymerase chain reaction.}

\section{Acknowledgements}

This project has been funded in whole or in part with funds from the Bill \& Melinda Gates Foundations under Grant No. 45114 and with support from the UK Medical Research Council Grant No. MR/P025404/1.

\section{Authors' contributions}

JRD, FMH, DS and NFL performed the study design. JRD, RNB, HH, MW, NR, FRS, MSA and IW carried out the study implementation and data collection. JRD, RNB, NR, TAB and FMH performed the sample and study analysis and interpretation. JRD, RNB and FMH drafted and revised the manuscript. All authors read and approved the final manuscript. 


\section{Funding}

This project has been funded by the Bill \& Melinda Gates Foundations under Grant No. 45114. The funding body had no role in the design of the study, collection, analysis, and interpretation of data or in writing the manuscript.

\section{Availability of data and materials}

Data supporting the conclusions of this article are included within the article Raw data used and/or analyzed during the present study are available from the corresponding author upon reasonable request.

\section{Ethics approval and consent to participate}

This study was approved by the Universitas Hasanuddin Fakultas Kedokteran, number 273/H4.8.4.5.31/PP36-KOMETICK/2-18. The need for ethics approval for non-human subjects (which was determined to include performing human landing catches) was waived by the University of Notre Dame. All other ethical approvals were received by Department of Parasitology, Faculty of Medicine, Hasanuddin University, Makassar 90245, Indonesia.

\section{Consent for publication}

Not applicable.

\section{Competing interests}

The authors declare that they have no competing interests.

\section{Author details \\ ${ }^{1}$ Eck Institute for Global Health, University of Notre Dame, Notre Dame, Indi- ana 46556, USA. ${ }^{2}$ Department of Parasitology, Faculty of Medicine, Hasanud- din University, Makassar 90245, Indonesia. ${ }^{3}$ Eijkman Institute of Molecular Biology, Jakarta, Indonesia. ${ }^{4}$ Natural Resources Institute, University of Green- wich, Central Avenue, Chatham Maritime, Kent ME4 4TB, UK.}

Received: 4 September 2019 Accepted: 20 June 2020

Published online: 29 June 2020

\section{References}

1. Tumonggor MK, Karafet TM, Hallmark B, Lansing JS, Sudoyo H, Hammer MF, et al. The Indonesian archipelago: an ancient genetic highway linking Asia and the Pacific. J Hum Genet. 2013;58:165-73.

2. World Population. U.S. Census Bureau; 2018. https://www.census.gov/ popclock/print.php?component=counter. Accessed 10 Aug 2018.

3. Mittermeier RA, Mittermeier GG. Megadiversity: earth's biologically wealthiest nations. Mexico City: CEMEX; 1997.

4. Elyazar IRF, Hay SI, Baird JK. Malaria distribution, prevalence, drug resistance and control in Indonesia. Adv Parasitol. 2011;74:41-175.

5. Service M, Townson H. The Anopheles vector. In: Gilles HM, Warrell DA, editors. Essential malariology. 4th ed. London: Arnold; 2002. p. 59-84.

6. Hay SI, Sinka ME, Okara RM, Kabaria CW, Mbithi PM, Tago CC, et al. Developing global maps of the dominant Anopheles vectors of human malaria. PLoS Med. 2010;7:e1000209.

7. Elyazar IRF, Sinka ME, Gething PW, Tarmidzi SN, Surya A, Kusriastuti $\mathrm{R}$, et al. The distribution and bionomics of Anopheles malaria vector mosquitoes in Indonesia. Adv Parasitol. 2013;83:173-266.

8. Sugiarto, Kesumawati Hadi U, Soviana S, Hakim L. Confirmation of Anopheles peditaeniatus and Anopheles sundaicus as malaria vectors (Diptera: Culicidae) in Sungai Nyamuk Village, Sebatik Island North Kalimantan, Indonesia using an enzyme-linked immunosorbent assay. J Med Entomol. 2016;53:1422-4.

9. Simmons CP, Farrar JJ, Nguyen WV, Wills B. Dengue. N Engl J Med. 2012;366:1423-32.

10. Wardhani P, Aryati A, Yohan B, Trimarsanto H, Setianingsih TY, Puspitasari $D$, et al. Clinical and virological characteristics of dengue in Surabaya, Indonesia. PLoS One. 2017;12:e0178443.

11. Kosasih H, de Mast Q, Widjaja S, Sudjana P, Antonjaya U, Ma'roef C, et al. Evidence for endemic chikungunya virus infections in Bandung, Indonesia. PLoS Negl Trop Dis. 2013;7:e2483.

12. Laras K, Sukri NC, Larasati RP, Bangs MJ, Kosim R, Djauzi, et al. Tracking the re-emergence of epidemic chikungunya virus in Indonesia. Trans $R$ Soc Trop Med Hyg. 2005;99:128-41.
13. Chevalier V, de la Rocque S, Baldet T, Vial L, Roger F. Epidemiological processes involved in the emergence of vector-borne diseases: West Nile fever, Rift Valley fever, Japanese encephalitis and Crimean-Congo haemorrhagic fever. Rev Sci Tech. 2004;23:535-55.

14. Miller BR, Godsey MS, Crabtree MB, Savage HM, Al-Mazrao Y, Al-Jeffri $\mathrm{MH}$. Isolation and genetic characterization of Rift Valley fever virus from Aedes vexans arabiensis, Kingdom of Saudi Arabia. Emerg Infect Diseases. 2002;8:1492-4.

15. Burkot T, Durrheim D, Melrose W, Speare R, Ichimori K. The argument for integrating vector control with multiple drug administration campaigns to ensure elimination of lymphatic filariasis. Filaria J. 2006;5:10.

16. Suguri S, Cabrera BD, Shibuya T. Vector mosquitoes of Wuchereria bancrofti at Bicol region in the Philippines. 1. Transmission capability. Jpn J Exp Med. 1985;55:61-5.

17. Schultz GW. A study of bancroftian filariasis on the islands of Batan and Rapu Rapu, Philippines. SE J Trop Med. 1988;19:207-14.

18. Walker ED, Torres EP, Villanueva RT. Components of the vectorial capacity of Aedes poicilius for Wuchereria bancrofti in Sorsogon province, Philippines. Ann Trop Med Parasitol. 1998;92:603-14.

19. Belkin JN. The mosquitoes of the South Pacific (Diptera, Culicidae). Berkeley: University of California Press; 1962.

20. Huang YM. Contributions to the mosquito fauna of Southeast Asia. XIV. The subgenus Stegomyia of Aedes in Southeast Asia I - the Scutellaris group of species. Amer Ent Inst. 1972;9:1-109.

21. Clements AN. The biology of mosquitoes. Cambridge: CABI; 2012.

22. Bram RA. Contributions to the mosquito fauna of Southeast Asia. II. The genus Culex in Thailand (Diptera: Culicidae). Am Ent Inst. 1967;2:296.

23. Carpenter SJ, LaCasse WJ. Mosquitoes of North America north of Mexico. Berkeley: University of California Press; 1955.

24. Sirivanakarn S. Medical entomology studies. III. A revision of the subgenus Culex in the oriental region (Diptera: Culicidae). Am Ent Inst. 1976;12:272.

25. Harbach RE. The mosquitoes of the subgenus Culex in southwestern Asia and Egypt (Diptera: Culicidae). Am Ent Inst. 1988;24:1-240.

26. Converse JD, Tan RI, Rachman IT, Lee VH, Shope RE. Ingwavuma virus (Simbu group) from Culex and Mansonia mosquitoes (Diptera: Culicidae) in Indonesia. J Med Entomol. 1985;22:339-42.

27. Hoshino K, Isawa H, Tsuda Y, Yano K, Sasaki T, Yuda M, et al. Genetic characterization of a new insect flavivirus isolated from Culex pipiens mosquito in Japan. Virology. 2007;359:405-14.

28. Tjitra E, Anstey NM, Sugiarto P, Warikar N, Kenangalem E, Karyana M, et al. Multidrug-resistant Plasmodium vivax associated with severe and fatal malaria: a prospective study in Papua, Indonesia. PLoS Med. 2008:5:e128

29. WHO. Indonesia, Malaria. Geneva: World Health Organization; 2018. https://web.archive.org/web/20180121091308, http://www.searo.who. int/indonesia/topics/malaria/en. Accessed 31 July 2018.

30. WHO. World malaria report 2017. Geneva: World Health Organization; 2017.

31. Service MW. Mosquito ecology. Field sampling methods. New York: Elsevier Science Publishers; 1993.

32. Achee NL, Youngblood L, Bangs MJ, Lavery JV, James S. Considerations for the use of human participants in vector biology research: a tool for investigators and regulators. Vector Borne Zoonotic Dis. 2015;15:89-102.

33. WHO. Roll back malaria partnership: the global malaria action plan for a malaria free world. Geneva: World Health Organization; 2008. https:// www.unhcr.org/4afac5629.pdf.

34. WHO. Achieving and maintaining universal coverage with long-lasting insecticidal nets for malaria control. Geneva: World Health Organization 2017. http://apps.who.int/iris/bitstream/handle/10665/259478/WHOHTM-GMP-2017.20-eng.pdf? sequence=1. Accessed 26 June 2019.

35. Gimnig JE, Walker ED, Otieno P, Kosgei J, Olang G, Ombok M, et al. Incidence of malaria among mosquito collectors conducting human landing catches in western Kenya. Am J Trop Med Hyg. 2013;88:301-8.

36. Wotodjo AN, Trape J-F, Richard V, Doucouré S, Diagne N, Tall A, et al. No difference in the incidence of malaria in human-landing mosquito catch collectors and non-collectors in a Senegalese village with endemic malaria. PLoS One. 2015;10:e0126187.

37. Killeen GF, Marshall JM, Kiware SS, South AB, Tusting LS, Chaki PP, et al. Measuring, manipulating and exploiting behaviours of adult 
mosquitoes to optimise malaria vector control impact. BMJ Glob Health. 2017;2:e000212.

38. Russell TL, Beebe NW, Cooper RD, Lobo NF, Burkot TR. Successful malaria elimination strategies require interventions that target changing vector behaviours. Malar J. 2013;12:56.

39. Hawkes FM, Dabiré RK, Sawadogo SP, Torr SJ, Gibson G. Exploiting Anopheles responses to thermal, odour and visual stimuli to improve surveillance and control of malaria. Sci Rep. 2017;7:17283.

40. Abong'o B, Yu X, Donnelly MJ, Geier M, Gibson G, Gimnig J, et al. Host decoy trap (HDT) with cattle odour is highly effective for collection of exophagic malaria vectors. Parasit Vectors. 2018;11:533.

41. Whitten AJ, Mustafa M, Henderson GS. The ecology of Sulawesi. Gadjah Mada: Gadjah Mada University Press; 2001.

42. Myers N, Mittermeier RA. Biodiversity hotspots for conservation priorities. Nature. 2000;403:853.

43. Mittermeier RA, Myers N, Mittermeier CG, Robles Gil P. Hotspots: Earth's biologically richest and most endangered terrestrial ecoregions. Mexico City: CEMEX; 1999

44. O'Connor C, Soepanta A. Illustrated key to female anophelines of Indonesia. Jakarta, Indonesia: Directorate of Communicable Disease, $\mathrm{MoH}$ and US Naval Medical Research; 1989.

45. Lee DJ, Hicks MM, Griffiths M, Debenham ML, Bryan JH, et al. The Culicidae of the Australasian region. Volume 7. Nomenclature, synonimy, literature, distribution, biology and relation to disease. Genus Culex. Subgenera Acallyntrum, Culex. Canberra: Australian Government Publishing Service; 1989.

46. Rudbeck L, Dissing J. Rapid, simple alkaline extraction of human genomic DNA from whole blood, buccal epithelial cells, semen and forensic stains for PCR. BioTechniques. 1998;4:588-90.

47. Lobo NF, Laurent BS, Sikaala CH, Hamainza B, Chanda J, Chinula D, et al. Unexpected diversity of Anopheles species in eastern Zambia: implications for evaluating vector behavior and interventions using molecular tools. Sci Rep. 2015:5:17952

48. St Laurent B, Cooke M, Krishnankutty SM, Asih P, Mueller JD, Kahindi $S$, et al. Molecular characterization reveals diverse and unknown malaria vectors in the western Kenyan highlands. Am J Trop Med Hyg. 2016:94:327-35.

49. Beebe NW, Saul A. Discrimination of all members of the Anopheles punctulatus complex by polymerase chain reaction-restriction fragment length polymorphism analysis. Am J Trop Med Hyg. 1995;53:478-81.

50. Scott JA, Brogdon WG, Collins FH. Identification of single specimens of the Anopheles gambiae complex by the polymerase chain reaction. Am JTrop Med Hyg. 1993:49:520-9.

51. Benson DA, Clark K, Karsch-Mizrachi I, Lipman DJ, Ostell J, Sayers EW. GenBank. Nucleic Acids Res. 2014;42:D32-7.

52. Kitano T, Umetsu K, Tian W, Osawa M. Two universal primer sets for species identification among vertebrates. Int J Legal Med. 2007;121:423-7.

53. Kocher TD, Thomas WK, Meyer A, Edwards SV, Pääbo S, Villablanca FX, et al. Dynamics of mitochondrial DNA evolution in animals: amplification and sequencing with conserved primers. Proc Natl Acad Sci USA. 1989:86:6196-200.

54. Lambert AJ, Lanciotti RS. Consensus amplification and novel multiplex sequencing method for $\mathrm{S}$ segment species identification of 47 viruses of the Orthobunyavirus, Phlebovirus, and Nairovirus genera of the family Bunyaviridae. J Clin Microbiol. 2009:47:2398-404.

55. Kuno G, Chang GJ, Tsuchiya KR, Karabatsos N, Cropp CB. Phylogeny of the genus Flavivirus. JVirol. 1998;72:73-83.

56. Kuno G. Universal diagnostic RT-PCR protocol for arboviruses. J Virol Methods. 1998;72:27-41.

57. Ledermann JP, Zeidner N, Borland EM, Mutebi JP, Lanciotti RS, Miller BR, et al. Sunguru virus: a novel virus in the family Rhabdoviridae isolated from a chicken in north-western Uganda. J Gen Virol. 2014;95:1436-43.

58. R Core Team. R: a language and environment for statistical computing Vienna: R Foundation for Statistical Computing; 2018

59. Venables WN, Ripley BD. Modern applied statistics with S. 4th ed. New York: Springer; 2002

60. Hothorn T, Bretz F, Westfall P. Simultaneous inference in general parametric models. Biom J Biom Z. 2008:50:346-63.

61. Costantini C, Gibson G, Sagnon NF, Torre AD, Brady J, Coluzzi M. Mosquito responses to carbon dioxide in West African Sudan savanna village. Med Vet Entomol. 1996:10:220-7.
62. Laurent B, Oy K, Miller B, Gasteiger EB, Lee E, Sovannaroth S, et al. Cow-baited tents are highly effective in sampling diverse Anopheles malaria vectors in Cambodia. Malar J. 2016:15:440.

63. Ritthison W, Tainchum K, Manguin S, Bangs MJ, Chareonviriyaphap T. Biting patterns and host preference of Anopheles epiroticus in Chang Island, Trat Province, eastern Thailand. J Vector Ecol. 2014;39:361-71.

64. Gunathilaka N, Denipitiya T, Hapugoda M, AbeyewickremeW, Wickremasinghe R. Determination of the foraging behaviour and blood meal source of malaria vector mosquitoes in Trincomalee District of Sri Lanka using a multiplex real time polymerase chain reaction assay. Malar J. 2016;15:242.

65. Sriwichai P, Karl S, Samung Y, Sumruayphol S, Kiattibutr K, Payakkapol A, et al. Evaluation of $C D C$ light traps for mosquito surveillance in a malaria endemic area on the Thai-Myanmar border. Parasit Vectors. 2015;8:636.

66. Leung GH, Baird RW, Druce J, Anstey NM. Zika virus infection in Australia following a monkey bite in Indonesia. Southeast Asian J Trop Med Public Health. 2015:46:5.

67. Simonsen PE, Mwakitalu ME. Urban lymphatic filariasis. Parasitol Res. 2013;112:35-44

68. Partono F, Hudojo, Sri Oemijati N, Noor N, Borahina JH, Clarke MD, et al. Malayan filariasis in Margolembo, South Sulawesi, Indonesia. SE Asian J Trop Med Pub Health. 1972;3:537-43.

69. Mackenzie JS, Gubler DJ, Petersen LR. Emerging flaviviruses: the spread and resurgence of Japanese encephalitis, West Nile and dengue viruses. Nat Med. 2004;10:598-109.

70. Chen WR, Rico-Hesse R, Tesh RB. A new genotype of Japanese encephalitis virus from Indonesia. Am J Trop Med Hyg. 1992;47:61-9.

71. Lien JC, Lu LC, Shroyer DA, Baker RH, Rosen L. Experimental vertical transmission of Japanese encephalitis virus by Culex tritaeniorhynchus and other mosquitoes. Am JTrop Med Hyg. 1989;40:548-56.

72. Brown SE, Gorman BM, Tesh RB, Knudson DL. Coltiviruses isolated from mosquitoes collected in Indonesia. Virology. 1993;196:363-7.

73. Powers AM. Overview of emerging arboviruses. FutureVirol. 2009;4:391-401.

74. Porter KR, Tan R, Istary Y, Suharyono W, Widjaja S, Ma'Roef C, et al. A serological study of chikungunya virus transmission in Yogyakatra, Indonesia: evidence for the first outbreak since 1982. SE Asian J Trop Med. 2004:35:8.

75. Kwong JC, Druce JD, Leder K. Zika virus infection acquired during brief travel to Indonesia. Am J Trop Med Hyg. 2013;89:516-7.

76. Kenea O, Balkew M, Tekie H, Gebre-Michael T, Deressa W, Loha E, et al. Comparison of two adult mosquito sampling methods with human landing catches in south-central Ethiopia. Malar J. 2017;16:30.

77. Linton YM, Dusfour I, Howard TM, Manh ND, Dinh TH, et al. Anopheles (Cellia) epiroticus (Diptera: Culicidae), a new malaria vector species in the Southeast Asian sundaicus complex. Bull Entomol Res. 2005;95:329-39.

78. Manguin S, Garros C, Dusfour I, Harbach RE, Coosemans M. Bionomics, taxonomy, and distribution of the major malaria vector taxa of Anopheles subgenus Cellia in Southeast Asia: an updated review. Infect Genet Evol. 2008:8:489-503.

79. Collins RT, Jung RK, Anoez H, Sutrisno RH, Putut D. A study of the coastal malaria vectors, Anopheles sundaicus (Rodenwaldt) and Anopheles subpictus grassi, in South Sulawesi, Sulawesi, Indonesia. Geneva: World Health Organization; 1979. https://apps.who.int/iris/handle/10665/65780.

80. Wigati R, Mardiana Arianti Y, Mujiono. The incrimination of An. vagus Donitz, 1902 (Diptera: Culicidae) as a malaria vector in Kecamatan Kokap, Kulonprogo Regency. Sci Kes. 2006;2006(19):503-16.

81. AmerasinghePH,AmerasingheFP, Konradsen F, Fonseka KT, Wirtz RA. Malaria vectors in a traditional dry zone village in Sri Lanka. Am J Trop Med Hyg. 1999;60:421-9.

82. Gingrich JB, Weatherhead A, Sattabongkot J, Pilakasiri C, Wirtz RA. Hyperendemic malaria in a Thai village: dependence of year-round transmission on focal and seasonally circumscribed mosquito (Diptera: Culicidae) habitats. J Med Entomol. 1990;27:1016-26.

83. Lyengar MOT. Studies on the epidemiology of filariasis in Travancore. Calcutta: Thacker, Spink \& Co.; 1938.

84. Carter HF. Records of filaria infections in mosquitoes in Ceylon. AnnTrop Med Parasitol. 1948:42:312-21.

85. Karabatsos N. International catalogue of arboviruses, including certain other viruses of vertebrates. 3rd ed. San Antonio: American Society of Tropical Medicine and Hygiene for The Subcommittee on Information Exchange of the American Committee on Arthropod-borne Viruses; 1985.

86. Vythilingam I, Oda K, Chew TK, Mahadevan S, Vijayamalar B, Morita K, et al. Isolation of Japanese encephalitis virus from mosquitoes collected 
in Sabak Bernam, Selangor, Malaysia in 1992. J Am Mosquito Contr. 1995;11:94-8.

87. Turell MJ, Dohm DJ, Sardelis MR, O'Guinn ML, Andreadis TG, Blow JA. An update on the potential of North American mosquitoes (Diptera: Culicidae) to transmit West Nile virus. J Med Entomol. 2018;42:6.

88. O Berge T. International catalogue of arboviruses; including certain other viruses of vertebrates. 2nd ed. Atlanta: Centers for Disease Control and Prevention; 1975.

89. Sucharit S, Surathin K, Shrestha SR. Vectors of Japanese encephalitis virus (JEV): species complexes of the vectors. Southeast Asian J Trop Med Public Health. 1989;20:611-21.

90. Chan A, Chiang L-P, Hapuarachchi HC, Tan C-H, Pang SC, Lee R, et al. DNA barcoding: complementing morphological identification of mosquito species in Singapore. Parasit Vectors. 2014;7:569.

91. Sodhi NS, Koh LP, Brook BW, Ng PKL. Southeast Asian biodiversity: an impending disaster. Trends Ecol Evol. 2004;19:654-60.

92. Takken W, Knols BGJ. A taxonomic and bionomic review of the anopheline vectors of Indonesia. In: Takken W, Snellen WB, Verhave JP, Knols BG J Atmosoedjono S, editors. Environmental measures for malaria control in Indonesia: a historical review on species sanitation. Wageningen: Wageningen Agricultural University Papers; 1991. p. 9-62.

93. Dusfour l, Harbach RE, Manguin S. Bionomics and systematics of the oriental Anopheles sundaicus complex in relation to malaria transmission and vector control. Am J Trop Med Hyg. 2004;71:518-24.

94. Sumruayphol S, Apiwathnasorn C, Komalamisra N, Ruangsittichai J, Samung Y, Chavalitshewinkoon-Petmitr P. Bionomic status of Anopheles epiroticus Linton \& Harbach, a coastal malaria vector, in Rayong Province, Thailand. Southeast Asian J Trop Med Public Health. 2010;41:7.

95. MogiM,SunaharaT,Selomo M. Mosquito and aquatic predator communities in ground pools on lands deforested for rice field development in central Sulawesi. Indonesia. J Am Mosquito Contr. 1999;15:92-7.
96. Mogi M, Memah V, Miyagi I,TomaT, Sembel DT.Mosquito (Diptera:Culicidae) and predator abundance in irrigated and rain-fed rice fields in North Sulawesi. Indonesia. J Med Entomol. 1995;32:361-7.

97. Takken W, Knols BGJ, Otten H. Interactions between physical and olfactory cues in the host-seeking behaviour of mosquitoes: the role of relative humidity. Ann Trop Med Parasit. 1997;91:S119-20.

98. Opayele AV, Adekunle AJ, Ibrahim KT, Olaleye DO. Influence of meteorological variables on diversity and abundance of mosquito vectors in two livestock farms in Ibadan, Nigeria: public health implications. J Mosq Res. 2017;7:70-8.

99. Stoops CA, Rusmiarto S, Susapto D, Munif A, Andris H, Barbara KA, et al. Bionomics of Anopheles spp.(Diptera: Culicidae) in a malaria endemic region of Sukabumi, West Java, Indonesia. J Vector Ecol. 2009;34:200-7.

100. Mahanta B, Handique R, Dutta P, Narain K, Mahanta J. Temporal variations in biting density and rhythm of Culex quinquefasciatus in tea agro-ecosystem of Assam, India. SE Asian J Trop Med. 1999;30:804-9.

101. PipitgoolV,Waree P, Sithithaworn P, LimvirojW. Studies on biting density and biting cycle of Culex quinquefasciatus, Say in Khon Kaen City, Thailand. SE Asian J Trop Med. 1998;29:333-6.

102. Tsuda Y, Komagata O, Kasai S, Hayashi T, Nihei N, Saito K, et al. A mark-releaserecapture study on dispersal and flight distance of Culex pipiens pallens in an urban area of Japan. J Am Mosquito Contr. 2008;24:339-43.

\section{Publisher's Note}

Springer Nature remains neutral with regard to jurisdictional claims in published maps and institutional affiliations.
Ready to submit your research? Choose BMC and benefit from:

- fast, convenient online submission

- thorough peer review by experienced researchers in your field

- rapid publication on acceptance

- support for research data, including large and complex data types

- gold Open Access which fosters wider collaboration and increased citations

- maximum visibility for your research: over 100M website views per year

At BMC, research is always in progress.

Learn more biomedcentral.com/submissions 